\title{
Modifying Balanced Scorecard as a Strategic Tool of Public Sector Organisations: Evidence from a Community Health Centre in Indonesia
}

\author{
Rudy M. Harahap ${ }^{1 *}$ and Farkhan Wisnu Wardhono² \\ 'University of Bina Nusantara, South Jakarta, Indonesia \\ ${ }^{2}$ STAN Polytechnic, Indonesia
}

\begin{abstract}
To improve public health services, Indonesia has decentralised Community Health Centres, commonly known as "Puskesmas" to local governments. As a public sector organisation funded by central and local governments these Centres must be accountable to the people. Therefore, central and local governments have required these Centres to provide better public health services to citizens. However, little is known on how these Centres develop and implement their strategies. Thus, the aim of this study is to explore the practices of developing and implementing strategies in these Centres. Methodology Approach: The study employed qualitative research approach. To collect data, interviews and document analysis were conducted in a Centre as a case study. Then, the collected data were analysed thematically. Specifically, the study reviewed the Centre's strategic plan year 2016-2020 as well as its vision and missions, strategic objectives, and the evaluation of this plan. Also, the study assessed on how balanced scorecard helped the case study in realising its vision, missions, and objectives. Findings: Using the lens of Kaplan and Norton's balanced scorecard, the study shows the formulated strategies in the case study. The case study used balanced scorecard as a tool to create and evaluate strategies, as well as measuring performance. Results of the evaluation were used to establish the next strategic plans. Originality/ Value: The study gives insights on how balanced scorecard was used in a community health centre. It identifies several issues in strategy implementation and proposes modified balanced scorecard for analysing the strategic plans of community health centres in less developed countries.
\end{abstract}

Keywords: Balanced Scorecard, Health Services, Strategy Evaluation, Strategic Plans

\section{Introduction}

As an emerging country, Indonesia has implemented public health services since the presence of Dutch colonialist in $16^{\text {th }}$ century (Wasisto, et al., 2009). At that time, the Dutch colonialist established a program to prevent pox and cholera diseases in Indonesia that feared most of the citizens. After independence, Indonesian government concerned more with these services.

For example, in 1968 there was a national meeting in Indonesia to discuss the lack of integration of health agencies. From the minutes of the meeting, Indonesian central government established local public health services that integrated all healthcare providers in different agencies, which was called as Community Health Centres or 'Puskesmas'. These Centres were a first tier of health facility service providers available in sub-district area (kecamatan). Their main responsibility was to serve citizens who needed general check-up and medical supports or treatments.

Principally, there were two kinds of Centres, those with beds and those without one. The Centres without beds generally served out patients, mostly were available during the day, and were not likely be prepared dealing with an obstetric emergency outside the clinic office hours. They had general medical doctors and midwife who provided preventative and curative services

*Email: rudy.m.harahap@binus.ac.id. 
related to health programs, such as antenatal cares and family planning programs.

The Centres were characterised as under-burdened and problematic as they tended to bypass critical-ill patients to higher tier of health service providers such as public and private hospitals. For example, when critical-ill patients visited this type of health facility, the staff were more likely just to transfer these patients to the next tiers of health service providers, such as hospitals with grade E, D, C, B, or A, instead of attempting to provide first aids or prepare these patients for transfer ${ }^{1}$.

When a new social health insurance benefit program was introduced, the Centres were required charging their fees to BPJS, a new established social health insurance benefit administration agency. This agency had an obligation to collect premiums or contributions from citizens who participated in the program. Then, participants of the program could receive rewards such as receiving free medical services in healthcare service facilities tall tiers. However, before receiving these medical services, they had to be registered and checked by one of the Centres first for referencing.

Besides charging the fees to BPJS, the Centres might also charge levies to patients who were not the participants of BPJS. Moreover, besides receiving funds from these general patients, the Centres could also receive additional funds from the central and local governments. Usually, they used these additional funds to support daily operating activities, such as maintaining asset, repairing treatment rooms and other supporting facilities, providing medical tools, and supplying generic medicines needed by the patients.

Because the Centres received public funds from central and local governments, they must be accountable to assure these funds were used for providing health

${ }^{1}$ Hospitals with grade $\mathrm{E}$ treated special healthcare. For example, they were psychiatric hospitals, leprosy hospitals, mother and children hospitals, and heart disease hospitals. Hospitals with grade D to A had less facilities compared to hospitals with grade $\mathrm{E}$. services and other operational activities. To be accountable, the Centres formulated their vision, missions, and strategic objectives. These objectives might be different among the Centres. However, the objectives should be aligned with central and local government policies and national healthcare program.

\section{The Case Study}

The case study was one of thirty-seven Centres in Semarang City of Indonesia. This Centre was very vital because the location was near the most crowded transportation area to transfer people across the cities and many traffic accidents happened there. The medical staff of the Centre often had to take emergency medical care's of accidental victims first before they were sent to the next-tiers healthcare facilities for better treatments. It means they had additional tasks beside routinely to serve or take cares people in the sub-district area near the Centre.

\section{Vision and Missions}

The management of the Centre had a responsibility to engage with staff in setting the goals of the Centre. This is a key condition to make employees participated in developing the goals and increased employee performance and ultimately improved organisational performance (Low and Teo, 2016; Poister, 2010).

After the goals were set, then the management of the Centre discussed the vision and missions with employees (David, et al., 2017). The vision and missions then were explained more in strategic planning sessions. From these sessions, strategic plans were issued every five-year. However, these plans could be revised when needed.

The vision of the Centre was:

"Become Community Health Centre with excellent care to create healthy living people".

Vision statement ideally is in one sentence, to be written from customer perspective, and should reveal the type 
of business the firm engages (David, et al., 2017). The Centre's vision is a statement with a clear future goal to create healthy living people. It created priorities to provide excellent care, so the vision still aligned with national health program to make a healthy environment in low level area and to decrease diseases and mortality rate. This vision statement is an answer to "What do we want to become?" A clear vision may provide foundation in developing comprehensive missions.

Moreover, vision statement needs to be understood by all of employees. One way to make it understandable is by creating mission statements. Basically, mission statements are to answer the question of "What is our business?" They describe the organisational values and priorities. Having a clear mission may compel leaders to think about the nature and scope of present activities and to evaluate potential activities. However, a mission statement is not only to chart the future direction, but it also serves as a constant reminder to employees why an organisation exists (David, et al., 2017).

From the vision statement, the Centre developed two mission statements:

"Give first tier healthcare with professional, excellent, equal and affordable".

"Empower and encourage people and family to make healthy behaviour as the people needs".

It can be seen from the Centre's mission statements that the Centre realised its vision by providing excellent healthcare and building healthy environment. These statements are more obvious rather than the vision statement. Like the other Centres in Semarang City, the Centre developed two mission statements after considering internal stakeholders and suggestions from above government agency (the Health Agency of Semarang City) (Ulandari and Indrayanthi, 2016).

\section{Strategic Objectives}

Organisations may use various approaches to create strategic objectives. Government organisations in
Indonesia had five-year strategic objectives shown formally in strategic plan documents. During these five years, government organisations conducted formal evaluations and could revised their strategic plan documents. This revision was usually applied when organisational leaders felt the existing strategic objectives were not relevant with current conditions.

The strategic objectives of the Centre were:

a. Increased the quality of management and human resources;

b. Increased the quantity and quality of infrastructures;

c. Increased the scope, type, and quality of services; and

d. Optimised revenue and expenditure's efficiency.

These strategic objectives were detailed into several programs. Employees then worked to reach the programs. Also, their performance was measured and evaluated annually. The achievement of the programs indicated that employees made excellent performance.

\section{Balanced Scorecard}

Kaplan and Norton (1992) introduce balanced scorecard to balance the perspectives of firm's performance. In the balanced scorecard, they suggest organisations to group their performance measures into four distinct perspectives: financial, customers, internal processes, and learning and growth.

They claim that balanced scorecard can be used to determine strategies (Kaplan and Norton, 2001). Furthermore, it has been suggested that greater balanced scorecard usage is associated with improved performance, regardless of firm sizes and product life cycle (Hoque and James, 2000). Moreover, Kaplan and Norton (2001) suggest that balanced scorecard can be applied in for-profit and not-for-profit organisations. Bain and Company found that $57 \%$ of firms worldwide used balanced scorecard, including $75 \%$ of large firms in North America (Rigby and Bilodeau, 2015).

On the other hand, because its benefits, public sector organisation has been expected to implement balanced 
score card. However, studies related to the use of balanced scorecard were mostly conducted in forprofit organisations. Additionally, Akbar, et al. (2017) opine that adopting balanced scorecard measurement from private sector organisations is problematic since the different characteristics and objectives of public sector organisations compared to private sector organisations.

The common error in implementing balanced scorecard is to view balanced score card only operating as a reporting mechanism (Gauthier, et al., 2003). This view may lead to public sector organisations have too many performance measures, but their management is unable to focus on critical information. To reduce these negative consequences, balanced scorecard should be viewed as a key management tool in telling performance stories of strategy implementation. As a result, balanced scorecard can be proved as a well-accepted management practice in public sector organisations (Nor, 2012).

Balanced score card's basic idea is that organisations should establish objectives and evaluate their strategies based on various criteria. It means that although financial measures are important in organisational strategic planning, other measures are also important, such as customer services, employee morale, product quality, pollution abatement, business ethics, social responsibility, community involvement, and other items.

\section{The Centre's Balanced Scorecard Perspectives}

In the case study, the Centre used four perspectives of balanced scorecard to define its strategic objectives. Furthermore, it used balanced score card as a tool to evaluate its strategic objectives. The overall purpose of using balanced scorecard was to balance organisational objectives from the perspective of customers or medical patients and internal organisation. It means balanced scorecard was used to bridge the needed conditions from customers and internal organisation's perspectives (Cardos and Candela, 2009).
The first perspective of the Centre's balanced scorecard was learning and growth. This perspective answers the question: "Can we continue to improve and create value?" Details of the perspective are shown in (Table 1).

Learning and growth perspective may be defined as the detection and correction of errors (Kaplan and Norton, 1992). It connects organisational learning with human resource management practices, as the first instance subject of organisational learning.

The Centre had many things to do in creating excellent services shown in the learning and growth perspective. However, this perspective had too many indicators and targets since the Centre was the main core public health service in the sub-district area. It seems that the Centre tried to improve several sectors at the same time, such as human resources, infrastructures, and medical-related services. Improving human resources was executed through training and establishing employee rules. The Centre improved and maintained infrastructures to make employees and medical patients safe and comfortable in using their tools and facilities.

From interviewing one of the Centre's employees, it was noticed that the Centre almost achieved half of the targets in one semester. For example, the discipline of employees relatively improved with no employee violated the work hours. Like this target, infrastructures in the Centre were relatively well-maintained and available to use. Building, ambulance units, treatment rooms, administration desks, playground for children, parking area, and toilets were all well-maintained, so the satisfaction rate of medical patient's improved better than the previous year. However, the Centre still needed additional medical tools, which were important for taking care medical patients, such as sterilisation tools and patient beds.

Unlike these two indicators and targets, the indicator and target related to medical services needed more attention. It was because the Centre still faced many patients who got blood fever disease in their subdistrict area during the rainy or wet seasons. This condition became a local issue and the Semarang 
Table 1. Learning and growth perspective

\begin{tabular}{|c|c|c|}
\hline Targets & Indicators & Programs \\
\hline $\begin{array}{l}\text { Increasing the prosperity of } \\
\text { employees }\end{array}$ & Indicator was not explicitly stated & Non-program \\
\hline Increasing the quality of care & $\begin{array}{l}\text { Documents; communication, water, and electricity care; office equipment and } \\
\text { inventories; maintenance care and permeance of office vehicles; office cleaning care; } \\
\text { office equipment repairing care; office stationery; printing and duplication; electricity } \\
\text { installation; household equipment; and food and beverages. }\end{array}$ & Office administration care program \\
\hline $\begin{array}{l}\text { Increasing the disciplinary of } \\
\text { employees }\end{array}$ & Employee attendance rate; employee uniform; and work field uniform & Employee discipline program \\
\hline $\begin{array}{l}\text { Increasing the capacity of human } \\
\text { resources }\end{array}$ & $\begin{array}{l}\text { Employee who take formal course and training; regulation training; technical guidance } \\
\text { of law implementation; and functional course and training }\end{array}$ & Human resources capacity program \\
\hline $\begin{array}{l}\text { Increasing the quantity and quality } \\
\text { of employee' infrastructures }\end{array}$ & $\begin{array}{l}\text { Office inventories; office furniture; good-condition building; and office and operational } \\
\text { vehicles }\end{array}$ & Employee infrastructure program \\
\hline $\begin{array}{l}\text { Increasing the quantity and quality } \\
\text { of the Centre's infrastructures }\end{array}$ & Availability of drug and medicine; implementation of rationality medicine & Drugs and medicine program \\
\hline $\begin{array}{l}\text { Increasing the Centre's } \\
\text { infrastructures that functioned well }\end{array}$ & Quantity and quality of mobile community health centre & $\begin{array}{l}\text { Procurement, improvement, and } \\
\text { maintenance program }\end{array}$ \\
\hline $\begin{array}{l}\text { Decreasing disease and mortality } \\
\text { rate and preventing disability from } \\
\text { diseases }\end{array}$ & $\begin{array}{l}\text { Mosquitoes fogging; discovery and handling blood fever sufferer; discovery and } \\
\text { handling pneumonia toddler; discovery and handling TBC sufferer; discovery and } \\
\text { handling diarrhoeal sufferer; area of extraordinary handling }\end{array}$ & $\begin{array}{l}\text { Preventing and resolving disease } \\
\text { program }\end{array}$ \\
\hline $\begin{array}{l}\text { Increasing the community nutrient } \\
\text { cares and supporting family in } \\
\text { increasing health }\end{array}$ & $\begin{array}{l}\text { Bad nutrient toddler who get treatment; giving complementary food at infant 6-24 } \\
\text { months whom bad nutrient and poor family }\end{array}$ & Community nutrient program \\
\hline \multirow{2}{*}{$\begin{array}{l}\text { Increasing the health of mothers } \\
\text { and children and reproduction } \\
\text { healthiness }\end{array}$} & Baby visiting; handling new-born with complication; toddler care & Toddler healthcare program \\
\hline & $\begin{array}{l}\text { Pregnant mother visiting; handling pregnant mother with complication; delivery baby } \\
\text { by midwife-educated employees; afterbirth-mother care; active participant planned } \\
\text { family }\end{array}$ & $\begin{array}{l}\text { Mother and child safety delivery } \\
\text { program }\end{array}$ \\
\hline $\begin{array}{l}\text { Increasing the quality of health } \\
\text { environment }\end{array}$ & People who use toilet; clean water; healthy house; well-educated occurrence & Healthy environment program \\
\hline
\end{tabular}

City's local government concerned with this condition and gave "red alert" to the sub-district area. The Centre struggled to respond this alert and thus collaborated more with the local government might reduce the blood fever disease in the rest of semester.

The second perspective of the Centre's balanced scorecard was internal business process. This perspective is related to the question: "What must we excel at?" Details of this perspective are shown in (Table 2).

Kaplan and Norton (1996) suggest internal business process perspective starts with receiving customer orders and finishes with delivery of the products or services to customers. Jalaludin, et al. (2014) argues that internal business process perspective is mainly concerned with the operational side of organisations. Thus, the indicators and targets of this perspective
Table 2. Internal business process perspective

\begin{tabular}{lll}
\hline Target & Indicator & Program \\
\hline Increased quantity and & All indicators based on Minimum & Healthcare \\
quality of services & Health Service Standards & program \\
\hline
\end{tabular}

should be able to capture information that describes whether efficiency and effectiveness have been achieved throughout the operational side of the business. Examples of the indicators are measures of services, product quality, production cycle time, and process quality yields.

In the Centre, the business process started from receiving medical patients and finished with giving medical treatments and the needed medicines. The Centre just had one indicator and target in the internal business process perspective, which was to improve the services given to medical patients through daily operations. The 
Centre used the minimum health service standards as the criteria. Several service standards of the hospitals were used because the Centre was like a mini hospital. The way to improve the services then was decided in the job criteria and all of employees had to fulfil the criteria.

From interviews, it can be inferred that the management of the Centre used the minimum service standards to develop internal standard operating procedures related to medical services. They continuously developed and updated these procedures, such as for special disease treatments. These activities were needed because the Centre was a first-tier facility that should provide fast treatment properly when needed. The procedures were developed with assistance from general medical doctors in the Centre. They had more knowledge to compose the draft of the procedures. After drafted, then the management decided whether the draft was approved or not.

The third perspective of the Centre's balanced scorecard was financial. Financial perspective is to answer the question: "How do we look to shareholders?" In the Centre's context, the "shareholders" was changed to "stakeholders". Details of the perspective are shown in (Table 3).

Kaplan and Norton (1992) suggest that several performance measures are important in financial perspective, which are cash flow, sales growth, operating income, market share, and return on equity. These measures are a short-term financial result obtained in the competitive environment (Kaplan and Norton, 2000). However, performance measures of this perspective can be different at different stages of company's activities.

Besides focused on revenue side, financial perspective can be linked to the concept of "waste disposal" like cost reduction. This cost reduction may lead to further increase in financial returns, which may lead to a return to profitability in sales turnover and a high return on investment (Baroma, et al., 2013).

Unlike for-profit entities, maximising cost efficiency in not-for-profit or government organisations are achieved
Table 3. Financial perspective

\begin{tabular}{|l|l|l|}
\hline Targets & Indicators & Programs \\
\hline $\begin{array}{l}\text { Increasing the quantity } \\
\text { and quality of published } \\
\text { reports }\end{array}$ & $\begin{array}{l}\text { Ratio of planning and } \\
\text { reporting document } \\
\text { prepared on time }\end{array}$ & $\begin{array}{l}\text { Financial performance } \\
\text { system program }\end{array}$ \\
\hline Increasing revenue & $\begin{array}{l}\text { Revenue and financial } \\
\text { independency }\end{array}$ & $\begin{array}{l}\text { Optimization revenue } \\
\text { program }\end{array}$ \\
\hline $\begin{array}{l}\text { Increasing expenditure } \\
\text { rate efficiency }\end{array}$ & Efficiency & $\begin{array}{l}\text { Spending efficiency } \\
\text { program }\end{array}$ \\
\hline
\end{tabular}

by maximising the benefits of stakeholders within resource constraints (Jaget and Wet, 2007). Thus, the successful of financial measures in these organisations could be in the kinds of massive cost reductions, small deviations from the budget, performance changes in a short period of time, and increased return on investment. Hussain and Farooq (2011) argue these measures may increase organisational efficiency.

The "financial" word in the name of the perspective might sound unclear for not-for-profit organisations because they are not mainly targeted with financial outcomes. However, not-for-profit organisations have stakeholders. For example, they might be the members who founded an organisation. In this case, the financial perspective in these organisations may reflect "stakeholder interests" or "successful" perspective (Savkin, 2014). That is why the Centre's financial perspective had revenue indicator and target. It was stated as "increasing revenue" as charging service fees to general medical patients or non-participants of BPJS who visited the Centre. These fees are a "grey area" that may not be calculated as profit or revenue.

In contrast, expenditure efficiency rate may fit with the financial perspective of non-for-profit organisations. The Centre thus was required to be more aware and wiser in using the allocated budget as well as to be sensitive in budget expenditure. It had to use resources efficiently but still could give the best service quality to medical patients.

Interview results show that the Centre did not have critical issues in financial perspective. This condition happened because the Semarang City's local government intensively monitored and evaluated 
budget execution in the Centre. The local government also required the Centre to submit monthly financial reports and quarterly executive reports. These reports were used for evaluating the overall performance of the Centre compared with the executed budget.

The fourth or last perspective of the Centre's balanced scorecard was customer. This perspective is related to the question of "How do customers see us?" These customers mean medical patients who visited to the Centre. Details of the perspective are shown in (Table 4).

Mahdavi, et al. (2014) suggests customer perspective is to consider external customers' point of view, which is a crucial factor for creating financial success and revenue from selling products and services. In the public sector's balanced scorecard, "customers" refer to citizens or communities. Because the main objective of public sector organisations is not to maximise profit and shareholder return, customer perspective needs to be placed at the bottom of the four perspectives of balanced scorecard (Marr, 2019).

As shown in (Table 4), the Centre concerned with communities in its sub-district area. It wanted to improve services for special healthcare and make better behaviour of clean and healthy life. This was not directly related to medical patients who visited the Centre but to communities as a whole. For example, staff of the Centre visited members of households to give socialization and check their living environment to ensure that they were aware with disease prevention.

From interviewing one of the medical doctors in the Centre, there were several programs of community services, such as visiting and educating poor people, doing accompaniments and recording data of pregnant mothers, and monitoring integrated care camp in subdistrict area. The main issue in these activities was the Centre had insufficient employees who could carry on the services. So, employees did not visit the communities regularly. Furthermore, the Centre just had three general medical doctors, a dentist, and several midwifes. This condition placed the Centre in a difficult position as several of these employees had to be available in the
Table 4. Customer perspective

\begin{tabular}{|c|c|c|}
\hline Targets & Indicators & Programs \\
\hline $\begin{array}{l}\text { Improving special } \\
\text { healthcare }\end{array}$ & $\begin{array}{l}\text { - Level one emergency- } \\
\text { condition care } \\
\text { - Basic health poor people } \\
\text { - Poor people health reference } \\
\text { care } \\
\text { - Capability in handling life } \\
\text { saving } \\
\text { - Satisfaction of emergency- } \\
\text { condition customer }\end{array}$ & $\begin{array}{l}\text { Community } \\
\text { health effort } \\
\text { program }\end{array}$ \\
\hline $\begin{array}{l}\text { Improving clean and } \\
\text { health behaviour; and } \\
\text { improvement of health } \\
\text { effort from community }\end{array}$ & $\begin{array}{l}\text { - Active and prepared village } \\
\text { - Integrated care camp } \\
\text { (Posyandu) } \\
\text { - Family with clean and health } \\
\text { behaviour } \\
\text { - Healthiness of elementary } \\
\text { school }\end{array}$ & $\begin{array}{l}\text { Health } \\
\text { promotion and } \\
\text { role community } \\
\text { program }\end{array}$ \\
\hline
\end{tabular}

office and doing daily administrative tasks. To manage this issue, the management of the Centre arranged a shift schedule and assigned other employees (i.e. nurses or pharmacists) to handle these jobs.

\section{Concluding Remarks}

Community health centres have a responsibility to increase customer satisfaction through public health services and improving health environment around them. Through balanced scorecard, centres may express clearly their vision and missions and identify customer satisfaction more transparent, objective, and measurable. They can also improve the quality of human resources in reaching their vision and missions.

The Centre's balanced scorecard, as a case study, is clear evidence on how community health centres may develop, implement, and evaluate their strategies using balanced scorecard. Balanced scorecard was helpful to manage the Centre's strategies and performance. However, to be effective, its strategy-evaluation process needs to consider several characteristics of economical, meaningful, timely, and actual, not dominate decision, and simple (David, et al., 2017).

Moreover, developing balanced scorecard to achieve organisational strategic objectives also needs more considerations and deep analysis. The important step is to change the balanced scorecard perspectives of 
community health centres. Marr (2019) opines that this modification may generate a balanced scorecard that is relevant to strategy achievement.

In modifying balanced scorecard, first the centres need to move financial perspective position to the bottom. It is because the first main objective of most public sector organisations is not to maximise profits and shareholder return. Instead, money and infrastructure are resources to be managed efficiently to deliver strategic objectives. Second, the next main objective of public sector organisations is to deliver high quality services to their key stakeholders, which can be citizens or communities. So, it will be more appropriate to change the title of the centre's customer's perspective to "stakeholders" perspective. This perspective usually sits at the top of balanced scorecard to highlight the key receivers of deliverables and outcomes. The two remaining balanced scorecard perspectives may stay as they are since public sector organisations need to
Table 5. Comparison of old and modified balanced scorecards

\begin{tabular}{|l|l|}
\hline Old balanced scorecard & Modified balanced scorecard \\
\hline Learning and growth & Stakeholders \\
\hline Internal business process & Learning and growth \\
\hline Financial & Internal business process \\
\hline Customers & Financial \\
\hline
\end{tabular}

build the necessary human, information, and other organisational resources as the key processes. The comparison between the old balanced scorecard and the modified balanced scorecard is shown in (Table 5).

The next step after modifying the perspectives, the centres need to pay attention to the contents in each of the perspectives. Too many or few contents can be harmed to the achievement of organisational strategic objectives. Thus, it should be clear in describing organisational missions and strategies in performance indicators. Targets in each perspective should also be balanced among the four perspectives. These targets

Table 6. The modified balanced scorecard perspectives

\begin{tabular}{|c|c|c|}
\hline \multicolumn{3}{|l|}{ Perspective: Stakeholder } \\
\hline Targets & Indicators & Programs \\
\hline Improving healthcare quality & $\begin{array}{l}\text { - Rate of stakeholder satisfaction } \\
\text { - Queue rate in the administration process } \\
\text { - Treatment for emergency status patient }\end{array}$ & Excellent healthcare service program \\
\hline Improving clean and health environment & $\begin{array}{l}\text { - Disease and mortality rate } \\
\text { - Life expectancy rate in sub-district environment } \\
\text { - Healthy living in sub-district environment }\end{array}$ & Healthy living environment program \\
\hline \multicolumn{3}{|l|}{ Perspective: Learning and Growth } \\
\hline Target & Indicator & Program \\
\hline Improving the quality of human resources & $\begin{array}{l}\text { - Intensity of trained officials } \\
\text { - Office inventory needs }\end{array}$ & Official training program \\
\hline Increasing the infra-structures and facilities & $\begin{array}{l}\text { - Medicine and drug stock } \\
\text { - Maintaining and repairing the broken tools }\end{array}$ & $\begin{array}{l}\text { Infrastructure maintenance and procurement } \\
\text { program }\end{array}$ \\
\hline Improving the special treatment cases & $\begin{array}{l}\text { - Special disease that can be treated } \\
\text { - Healed expectancy of special disease }\end{array}$ & Special disease treatment program \\
\hline \multicolumn{3}{|l|}{ Perspective: Internal Business Process } \\
\hline Target & Indicator & Program \\
\hline $\begin{array}{l}\text { Increasing the quantity and quality of } \\
\text { healthcare services }\end{array}$ & $\begin{array}{l}\text { - Minimum service standards of general healthcare service } \\
\text { - Good practices service principle in public organisations }\end{array}$ & Best quality service program \\
\hline $\begin{array}{l}\text { Developing Standard Operating Procedures } \\
\text { (SOP) }\end{array}$ & $\begin{array}{l}\text { - Compliance performance } \\
\text { - SOP's development }\end{array}$ & SOP program \\
\hline \multicolumn{3}{|l|}{ Perspective: Financial } \\
\hline Target & Indicator & Program \\
\hline Increasing the quality of finance & $\begin{array}{l}\text { - Revenue from non-participants of BPJS } \\
\text { - Appropriate expenditure }\end{array}$ & Effective and efficient budget execution Program \\
\hline $\begin{array}{l}\text { Increasing the account-ability to the local } \\
\text { government }\end{array}$ & $\begin{array}{l}\text { - On time reporting budget execution } \\
\text { - Quality of reporting }\end{array}$ & Accountability and regulation program \\
\hline
\end{tabular}


should consist several essential targets that reflect organisational missions and strategies. It means the centres need to change balanced scorecard to be more principle-based rather than rule-based as shown in (Table 6).

Becoming a principle-based balanced scorecard does not mean that it will be more difficult to determine strategies. The positive effect to be more principlebased is management can develop strategic objectives and various ways to reach them. Even, it will simplify the performance evaluation process because less indicators and targets are shown in the perspectives. Less indicators and targets may not indicate weak performance.

However, using the modified balanced scorecard does not mean every problem in the centres can be eliminated. The idea is the modified balanced scorecard may provide new guidance on how to handle issues in the centres properly. It may also increase customer satisfaction rate and produce excellent performance. Yet, the modified balanced scorecard needs to be tested more in different contexts since it was developed based on a case study in a less-developed country. Further studies are needed to give deep analysis and provide evidence the feasibility of the modified balanced scorecard.

\section{References}

Akbar, M., Munawaroh, S. and Syahdan, S. A. (2017). Balanced scorecard implementation in public sector organisation, a problem? International Journal Accounting, Finance, and Economic. 1(1). https://journal.stkipsingkawang.ac.id/index.php/IJAFE/article/ view/557.

Baroma, B., Bellisario, A., Chirico, A. and Appolloni. (2013). A Breakthroughs in the Management Accounting Science: Imaging a balanced scorecard thought by lean philosophy rationales, Transit. Stud. Rev. 20:239-51. https://doi.org/10.1007/s11300-013-0279-1.

Cardos, M. and Candela, J. (2009). A review of the learning and growth perspective: A new approach to labour climate, International Journal of Management Science and Engineering Management. 4(4):243-59. https://doi.org/1 $0.1080 / 17509653.2009 .10671078$.
David, F. R. and David, F. R. (2017). Strategic Management: A Competitive Advantage Approach. 16th edition. Harlow: Pearson Education Limited. http://dl.booktolearn.com/ ebooks2/management/9781292148496_Strategic_ Management_2e1b.pdf.

Gauthier, J., Hagarty, D. and Wilson, C. (2003). Results using the balanced scorecard in the public sector, Journal of Corporate Real Estate. 6(1):53-63. https://doi. org/10.1108/14630010410812234.

Hoque, Z. and James, W. (2000). Linking balanced scorecard measures to size and market factors: Impact on organisational performance, Journal of Management Accounting Research. 12:1-17. https://doi. org/10.2308/jmar.2000.12.1.1. https://doi.org/10.2308/ jmar.2000.12.1.1.

Hussain, Z. and Farooq, A. (2011). Balanced scorecard perspective on change and performance: A study of selected Indian companies, Procedia - Social and Behavioral Sciences. 24:754-68. https://doi:10.1016/j. sbspro.2011.09.043. https://doi.org/10.1016/j. sbspro.2011.09.043

Jaget, P. and Wet, J. H. (2007). An appropriate financial perspective for a balanced scorecard, Southern African Business Review. 11(2):98-113.

Jalaludin, D., Nabiha, A. K. S. and Way, S. P. (2014). Managing environmental and economic performance: A review of theory and practice on performance measurement, The International Journal of Accounting and Business Society. 93-113.

Kaplan, R. S. (2001). Strategic performance measurement and management in non-profit organizations, Non-profit Management and Leadership. 11(3):353-70. https://doi. org/10.1002/nml.11308.

Kaplan, R. S. and Norton, D. (1992). The Balanced Scorecard-Measures that Drive Performance, Harvard Business Review, January-February 1992. https://hbr. org/1992/01/the-balanced-scorecard-measures-thatdrive-performance-2.

Kaplan, R. S. and Norton, D. (1996). The Balanced Scorecard: Translating Strategy into Action, Harvard Business School Publishing, Boston, MA. https://www. hbs.edu/faculty/Pages/item.aspx?num=8831.

Kaplan, R. S. and Norton, D. (2001). The Strategy-Focused Organisation: How Balanced Scorecard Companies Survive in the New Business Environment, Harvard Business School Publishing, Boston, MA. https://www. hbs.edu/faculty/Pages/item.aspx?num=5595.

Low, K. C. P. and Teo, T. C. (2016). The Impact of goal setting on employee effectiveness to improve organisation 
effectiveness: Empirical study of a high-tech company in Singapore, Journal of Business and Economic Policy. 3(1):82-97.

Mahdavi, A., Martens, B., \& Scherer, R. (2014). eWork and eBusiness in Architecture, Engineering and Construction: ECPPM 2014. CRC Press. Chicago.

Marr, B. (2019). Balanced Scorecard: How to Create a Public Sector BSC. Accessed on June 12, 2019. https:// bernardmarr.com/default.asp?contentID $=1473$.

Nor, W. (2012). Penerapan balanced scorecard pada pemerintah daerah, AUDI Jurnal Bisnis dan Akuntansi. 280-92.

Poister, T. H. (2010). The future of strategic planning in the public sector: Linking Strategic management and performance, Public Administration Review, Special Review. 246-54. https://doi.org/10.1111/j.15406210.2010.02284.x.
Rigby, D. and Bilodeau, B. (2015). Management Tools and Trends 2015, London: Bain \& Company. https://www. ydd.org.tr/wp-content/uploads/2017/12/BAIN_BRIEF_ Management_Tools_2015.pdf.

Savkin, A. (2014). Example of Nonprofit Balanced Scorecard with 14 KPIs. Accessed on June 14, 2019. https://bscdesigner.com/nonprofit-scorecard.htm.

Ulandari, L. P. S. and Indrayanthi, P. A. (2016). Basis for development of local public service primary healthcare business strategic plan in Gianyar District, Bali, Kesmas: National Public Health Journal. 11(2):86-93. https://doi. org/10.21109/kesmas.v11i2.846.

Wasisto, B., et al. (2009). Sejarah Pembangunan Kesehatan Indonesia 1973-2009. Kementerian Kesehatan Republik Indonesia (History of Health Sector Development in Indonesia). ISBN 9799254922. 